\title{
Resilience in Disasters: A Survey to The University Students in Lampung Province
}

\author{
Simon Sumanjoyo Hutagalung ${ }^{1}$, Ita Prihantika ${ }^{2}$
}

\author{
${ }^{1,2}$ Department of Public Administration \\ Universitas Lampung Bandar Lampung, Indonesia \\ Email: simon.sumanjoyo@fisip.unila.ac.id ita.prihantika@fisip.unila.ac.id
}

\begin{abstract}
Pandemics create various impacts in all sectors of life and groups. Youth who include student groups in University are vulnerable, even though they have good socio-economic categorization. The resilience of this group is facing the pandemic will have a positive social, political and economic impact on disaster recovery efforts. This study aimed to determine the degree of student groups resilience in Lampung Province in the covid-19 pandemic. The research method uses a quantitative approach with a questionnaire instrument distributed in a google form format and distributed to a sample group. Students who are active at state universities in Lampung Province. The findings of this research answer the anxiety of several parties regarding the resilience of student groups in dealing with various impacts of the pandemic.
\end{abstract}

Keywords: Resilience, Pandemic, Disaster Management, Higher Education.

\section{INTRODUCTION}

The Covid-19 pandemic that hit in 2020 had various impacts on many parties, including student groups. Their position as a group of young people studying at a university with various demands and varied workloads [1]. During the pandemic, habits that had previously been carried out were forced to adapt but still carry out their role as students. Resilience capacity then becomes an important thing to study considering these conditions [2]. Resilience is the concept of an individual's ability to overcome, go through, and return to its original condition after experiencing difficulties [3]. Increasing resilience is important because it can provide experience for individuals in dealing with problems and difficulties in their lives [4]. Resilience consists of seven aspects that support each other [5]; the identification of these aspects and indicators can be seen in the following table:

Table 1. Aspects of Resilience and its Indicators

\begin{tabular}{|c|c|c|c|}
\hline No & Aspects of & Indicators & Sub Indicators \\
\hline \multirow{4}{*}{1} & \multirow{4}{*}{$\begin{array}{c}\text { Emotion } \\
\text { Regulation }\end{array}$} & \multirow{3}{*}{$\begin{array}{l}\text { Able to } \\
\text { remain calm } \\
\text { when under } \\
\text { pressure }\end{array}$} & $\begin{array}{l}\text { 1. Not anxious or } \\
\text { stressed in dealing } \\
\text { with problems }\end{array}$ \\
\hline & & & $\begin{array}{l}\text { 2. Not easily } \\
\text { angry or sad }\end{array}$ \\
\hline & & & $\begin{array}{l}\text { 3. Stay focused on } \\
\text { what is being } \\
\text { done }\end{array}$ \\
\hline & & $\begin{array}{l}\text { Easy to } \\
\text { socialize }\end{array}$ & $\begin{array}{l}\text { 1. Easy to get } \\
\text { along with other }\end{array}$ \\
\hline
\end{tabular}

\begin{tabular}{|c|c|c|c|}
\hline No & Aspects of & Indicators & Sub Indicators \\
\hline & & & people \\
\hline & & & $\begin{array}{l}2 . \text { Have lots of } \\
\text { friends }\end{array}$ \\
\hline & & & $\begin{array}{l}\text { 3. Fun for other } \\
\text { people }\end{array}$ \\
\hline \multirow{6}{*}{2} & \multirow{6}{*}{$\begin{array}{l}\text { Impulse } \\
\text { Control }\end{array}$} & \multirow{3}{*}{$\begin{array}{c}\text { Not } \\
\text { aggressive }\end{array}$} & $\begin{array}{l}\text { 1. Not blaming } \\
\text { others }\end{array}$ \\
\hline & & & $\begin{array}{l}\text { 2. Not being } \\
\text { violent to others }\end{array}$ \\
\hline & & & $\begin{array}{l}\text { 3. Not imposing } \\
\text { your will on } \\
\text { others }\end{array}$ \\
\hline & & \multirow{3}{*}{$\begin{array}{l}\text { Able to } \\
\text { control } \\
\text { yourself }\end{array}$} & $\begin{array}{l}\text { 1. Not } \\
\text { overreacting to } \\
\text { something }\end{array}$ \\
\hline & & & $\begin{array}{l}\text { 2. Able to hold } \\
\text { your anger }\end{array}$ \\
\hline & & & $\begin{array}{l}\text { 3. No easily } \\
\text { influenced by the } \\
\text { surrounding } \\
\text { environment }\end{array}$ \\
\hline \multirow{5}{*}{3} & \multirow{5}{*}{$\begin{array}{l}\text { Optimism } \\
\text { (Optimism) }\end{array}$} & & $\begin{array}{l}\text { 1. Dare to express } \\
\text { opinions to others }\end{array}$ \\
\hline & & $\begin{array}{l}\text { Believing in } \\
\text { one's abilities }\end{array}$ & $\begin{array}{l}\text { 2. Understanding } \\
\text { one's strengths } \\
\text { and admitting } \\
\text { weaknesses in } \\
\text { oneself }\end{array}$ \\
\hline & & \multirow{3}{*}{$\begin{array}{l}\text { Having high } \\
\text { spirits }\end{array}$} & $\begin{array}{l}\text { 1. Not easily } \\
\text { discouraged }\end{array}$ \\
\hline & & & $\begin{array}{l}2 . \text { Trying to be } \\
\text { happy even } \\
\text { though they have } \\
\text { serious problems }\end{array}$ \\
\hline & & & $\begin{array}{l}\text { 3. Try harder if } \\
\text { they fail }\end{array}$ \\
\hline
\end{tabular}




\begin{tabular}{|c|c|c|c|}
\hline No & Aspects of & Indicators & Sub Indicators \\
\hline \multirow{6}{*}{4} & \multirow{6}{*}{$\begin{array}{l}\text { Ability to } \\
\text { Analyze } \\
\text { Problems } \\
\text { (Causal } \\
\text { Analysis) }\end{array}$} & \multirow{3}{*}{$\begin{array}{l}\text { Identify } \\
\text { problems } \\
\text { encountered }\end{array}$} & $\begin{array}{l}\text { 1. Able to } \\
\text { understand the } \\
\text { causes of } \\
\text { problems } \\
\text { encountered }\end{array}$ \\
\hline & & & $\begin{array}{l}\text { 2. Able to find } \\
\text { solutions to } \\
\text { problems they } \\
\text { have }\end{array}$ \\
\hline & & & $\begin{array}{l}\text { 3. Not rash in } \\
\text { making decisions }\end{array}$ \\
\hline & & \multirow{3}{*}{$\begin{array}{l}\text { Able to think } \\
\text { with common } \\
\text { sense }\end{array}$} & $\begin{array}{l}\text { 1. Realize that } \\
\text { humans have } \\
\text { limitations }\end{array}$ \\
\hline & & & $\begin{array}{l}\text { 2. Dislike } \\
\text { imagining }\end{array}$ \\
\hline & & & $\begin{array}{l}\text { 3. Thinking by } \\
\text { looking at the } \\
\text { reality that exists }\end{array}$ \\
\hline \multirow{6}{*}{5} & \multirow{6}{*}{ Empathy } & \multirow{3}{*}{$\begin{array}{l}\text { Able to grasp } \\
\text { non-verbal } \\
\text { language }\end{array}$} & $\begin{array}{l}\text { 1. Can understand } \\
\text { other people's } \\
\text { conditions }\end{array}$ \\
\hline & & & $\begin{array}{l}\text { 2. Sensitive to the } \\
\text { surrounding } \\
\text { environment }\end{array}$ \\
\hline & & & $\begin{array}{l}\text { 3. Willing to } \\
\text { listen to other } \\
\text { people's } \\
\text { complaints }\end{array}$ \\
\hline & & \multirow{3}{*}{$\begin{array}{l}\text { Also, feel } \\
\text { what other } \\
\text { people feel }\end{array}$} & $\begin{array}{l}\text { 1. Do not have } \\
\text { certain judgments } \\
\text { on everyone }\end{array}$ \\
\hline & & & $\begin{array}{l}\text { 2. Able to } \\
\text { position thyself } \\
\text { on the side of } \\
\text { others }\end{array}$ \\
\hline & & & $\begin{array}{l}\text { 3. Have a tolerant } \\
\text { attitude }\end{array}$ \\
\hline \multirow{6}{*}{6} & \multirow{6}{*}{$\begin{array}{c}\text { Self- } \\
\text { Efficacy }\end{array}$} & \multirow{3}{*}{$\begin{array}{l}\text { Having a } \\
\text { strong belief }\end{array}$} & $\begin{array}{l}\text { 1. Confidence in } \\
\text { being able to } \\
\text { solve the } \\
\text { problems } \\
\text { encountered }\end{array}$ \\
\hline & & & $\begin{array}{l}\text { 2. Convinced to } \\
\text { be able to change } \\
\text { for the better }\end{array}$ \\
\hline & & & $\begin{array}{l}\text { 3. Having a good } \\
\text { attitude in dealing } \\
\text { with problems }\end{array}$ \\
\hline & & \multirow{3}{*}{$\begin{array}{c}\text { Bearing } \\
\text { everything } \\
\text { about oneself }\end{array}$} & $\begin{array}{l}\text { 1. Dare to admit } \\
\text { misunderstanding }\end{array}$ \\
\hline & & & $\begin{array}{l}\text { 2. Completing } \\
\text { tasks completely }\end{array}$ \\
\hline & & & $\begin{array}{l}\text { 3. Ready to bear } \\
\text { the consequences } \\
\text { of his actions }\end{array}$ \\
\hline
\end{tabular}

\begin{tabular}{|c|c|c|c|}
\hline No & Aspects of & Indicators & Sub Indicators \\
\hline \multirow{6}{*}{7} & \multirow{6}{*}{$\begin{array}{c}\text { Achieveme } \\
\text { nt } \\
\text { (Reaching } \\
\text { Out) }\end{array}$} & \multirow{3}{*}{$\begin{array}{c}\text { Reawakening } \\
\text { the spirit } \\
\text { possessed } \\
\text { from } \\
\text { adversity }\end{array}$} & $\begin{array}{l}\text { 1. Believing there } \\
\text { will be wisdom in } \\
\text { every problem }\end{array}$ \\
\hline & & & $\begin{array}{l}\text { 2. Easy to forgive } \\
\text { others }\end{array}$ \\
\hline & & & $\begin{array}{l}\text { 3. Trying to rise } \\
\text { from sadness }\end{array}$ \\
\hline & & \multirow{3}{*}{$\begin{array}{l}\text { Able to be } \\
\text { free from } \\
\text { trauma in life }\end{array}$} & $\begin{array}{l}\text { 1. Able to accept } \\
\text { the reality of life }\end{array}$ \\
\hline & & & $\begin{array}{l}\text { 2. Not carried } \\
\text { away by the past }\end{array}$ \\
\hline & & & $\begin{array}{l}\text { 3. Focus on } \\
\text { designing the } \\
\text { future }\end{array}$ \\
\hline
\end{tabular}

Student and student groups are a reasonably large segment where the total population in Lampung Province in 2019 is 9,302,935 people; their number ratio covers $14.90 \%$ [6]. Based on the description and urgency of resilience capacity, there are several issues in this article: first, how is the resilience capacity of student groups during the pandemic? Secondly, what are the implications that stakeholders and decisionmakers need to follow up?

\section{RESEARCH METHODS}

This research was conducted with a quantitative approach and used a survey method. The population in this study were all active students in Lampung Province, while the sampling used was accidental sampling. According to [7], Accidental Sampling is a sampling technique based on chance; that is, any patient who coincidentally meets a researcher can be used as a sample if it is deemed that the person who happened to be met is suitable as a data source [8]. This sampling frame is related to the questionnaire instrument, made in a google form and distributed online to student groups in Lampung Province in the April-June 2020 period. The questionnaire consists of 7 aspects and 17 questions arranged on a Likert scale. After this period, it was known that 240 respondents answered the questionnaire, but then it was found that two respondents did not fill in the full answer so that the total respondents' answers were 238. The distribution of the sample includes several universities in Lampung Province, as follows: 
Table 2. Number of samples in the study

\begin{tabular}{|l|l|c|}
\hline No & Region & Sample \\
\hline 1 & Lampung University & 103 \\
\hline 2 & UIN Radin Intan & 72 \\
\hline 3 & Polinela & 56 \\
\hline 4 & Itera and others & 7 \\
\hline & Total & 238 \\
\hline
\end{tabular}

Following the type of research, quantitative data were analyzed using descriptive statistics using MS. Excel and SPSS. The use of MS. Excel in determining the scale and range of scales is for measuring the category of resilience assessment, while SPSS is used to analyze the questionnaire data obtained. The technique for determining the scale and scale range can be observed in the section below:
Determination of the Scale Range (RS) is carried out with the help of the following formula:

Formula: $\mathrm{nx}(\mathrm{N}-1) / \mathrm{N}$

$\mathrm{RS}=238 *(5-1) / 5$

$\mathrm{RS}=190$

Then the scale limit is determined as follows:
$\mathrm{MIN}=1 \mathrm{xn}$
238
$\mathrm{MAX}=5 \mathrm{xn}$
1190

The next step is to determine the scale using the scale range and the scale limit, while the scale used is in the Very Good to Very Bad range so that a range of scale values is produced as follows:

Table 3. Scale and Range Scale Formula

\begin{tabular}{|l|l|l|ll|}
\hline \multicolumn{1}{|c|}{ Scale } & \multicolumn{2}{c|}{ Formula Range Scale } & \multicolumn{3}{c|}{ Value Scale } \\
\hline Very Good & MIN + 4RS +1 & MIN + 5RS & $999-$ & 1188 \\
\hline Good & MIN + 3Rs + 1 & MIN + 4RS & $809-$ & 998 \\
\hline Simply Good & MIN + 2RS +1 & MIN + 3Rs & $619-$ & 808 \\
\hline Not Good & MIN + 1RS +1 & MIN+2RS & $429-$ & 618 \\
\hline Very Not Good & MIN & MIN+RS & $238-$ & 428 \\
\hline
\end{tabular}

This value range will be used to analyze the resilience of student groups based on the previously filled out questionnaire. Data analysis is carried out on each indicator and includes data analysis of all indicators.

\section{RESULTS AND DISCUSSION}

Based on distribution of answers obtained from the questionnaire, a score value and categorization coverage of each indicator and sub-indicator are generated, which are spread into seven aspects of resilience in the face of the Covid-19 pandemic disaster. Most of the values of these sub-indicators and indicators indicate the mental condition of students who can maintain good conditions, although if observed in detail, it will be found that several subindicators have values below the excellent category. In more detail, the distribution can be observed from the table below:

Table 4. Distribution of Values and Categorization of Student Group Resilience

\begin{tabular}{|c|c|c|c|c|c|c|c|c|}
\hline No & Aspect & Indicator & Sub Indicator & SI & Ind & Kat & Asp & Kat \\
\hline \multirow{6}{*}{1} & \multirow{6}{*}{$\begin{array}{l}\text { Emotion } \\
\text { Regulation }\end{array}$} & \multirow{3}{*}{$\begin{array}{l}\text { Able to remain calm } \\
\text { when under pressure }\end{array}$} & Not anxious or stressed & 924 & \multirow{3}{*}{877} & \multirow{3}{*}{$\mathrm{B}$} & \multirow{6}{*}{905} & \multirow{6}{*}{$\mathrm{B}$} \\
\hline & & & Not easily angry or sad & 848 & & & & \\
\hline & & & Stay focused in activities & 859 & & & & \\
\hline & & \multirow{3}{*}{ Easy to socialize } & 1. Easy to get along with other people & 976 & \multirow{3}{*}{943} & \multirow{3}{*}{ B } & & \\
\hline & & & 2. Have lots of friends & 1007 & & & & \\
\hline & & & 3. Pleasing to others & 854 & & & & \\
\hline \multirow{6}{*}{2} & \multirow{6}{*}{ Impulse Control } & \multirow{3}{*}{ Not aggressive } & 1. Not blaming others & 874 & \multirow{3}{*}{930} & \multirow{3}{*}{$\mathrm{B}$} & \multirow{6}{*}{914} & \multirow{6}{*}{$\mathrm{B}$} \\
\hline & & & 2. Not using violence & 931 & & & & \\
\hline & & & 3. Not forcing one's will & 984 & & & & \\
\hline & & \multirow{3}{*}{$\begin{array}{l}\text { Able to control } \\
\text { oneself }\end{array}$} & 1. Not overreacting & 968 & \multirow{3}{*}{894} & \multirow{3}{*}{$\mathrm{B}$} & & \\
\hline & & & 2. Able to hold anger & 860 & & & & \\
\hline & & & 3. Not easily influenced & 854 & & & & \\
\hline \multirow{3}{*}{3} & \multirow{3}{*}{ Optimism } & \multirow{2}{*}{$\begin{array}{l}\text { Believing in one's } \\
\text { abilities }\end{array}$} & 1. Dare to express opinions & 812 & \multirow[b]{2}{*}{664} & \multirow[b]{2}{*}{$\mathrm{CB}$} & \multirow{3}{*}{819} & \multirow{3}{*}{ B } \\
\hline & & & $\begin{array}{l}\text { 2. Understanding one's strengths and } \\
\text { weaknesses }\end{array}$ & 515 & & & & \\
\hline & & Having high spirits & 1. Not easily discouraged & 876 & 897 & $\mathrm{~B}$ & & \\
\hline
\end{tabular}




\begin{tabular}{|c|c|c|c|c|c|c|c|c|}
\hline No & Aspect & Indicator & Sub Indicator & SI & Ind & Kat & Asp & Kat \\
\hline & & & $\begin{array}{l}\text { 2. Trying to be happy even though he gets } \\
\text { press questions }\end{array}$ & 805 & & & & \\
\hline & & & 3. Try harder & 1011 & & & & \\
\hline \multirow{6}{*}{4} & \multirow{6}{*}{$\begin{array}{l}\text { Ability to } \\
\text { analyze } \\
\text { problems } \\
\text { (Causal } \\
\text { Analysis) }\end{array}$} & \multirow{3}{*}{$\begin{array}{l}\text { Identify the } \\
\text { problems } \\
\text { encountered }\end{array}$} & 1. Understand the causes of problems & 805 & \multirow{3}{*}{820} & \multirow{3}{*}{$\mathrm{B}$} & \multirow{6}{*}{969} & \multirow{6}{*}{ B } \\
\hline & & & 2. Able to find solutions to problems & 800 & & & & \\
\hline & & & 3. Not rash in decisions & 855 & & & & \\
\hline & & \multirow{3}{*}{$\begin{array}{l}\text { Able to think with } \\
\text { common sense }\end{array}$} & 1. Aware of having limitations & 990 & \multirow{3}{*}{985} & \multirow{3}{*}{ B } & & \\
\hline & & & 2. Does not like to fantasize & 962 & & & & \\
\hline & & & 3. Thinking with reality & 1003 & & & & \\
\hline \multirow{6}{*}{5} & \multirow{6}{*}{ Empathy } & \multirow{3}{*}{$\begin{array}{l}\text { Able to grasp non- } \\
\text { verbal language }\end{array}$} & $\begin{array}{l}\text { 1. Can understand other people's } \\
\text { conditions }\end{array}$ & 923 & \multirow{3}{*}{929} & \multirow{3}{*}{ B } & \multirow{6}{*}{968} & \multirow{6}{*}{ B } \\
\hline & & & 2. Sensitive to the environment & 921 & & & & \\
\hline & & & 3. Willing to listen to complaints & 944 & & & & \\
\hline & & \multirow{3}{*}{$\begin{array}{l}\text { Also, feel what } \\
\text { other people feel }\end{array}$} & $\begin{array}{l}\text { 1. Do not have certain judgments on } \\
\text { people }\end{array}$ & 886 & \multirow{3}{*}{985} & \multirow{3}{*}{ B } & & \\
\hline & & & 2. Able to position oneself & 1067 & & & & \\
\hline & & & 3. Have an attitude of tolerance & 1003 & & & & \\
\hline \multirow{6}{*}{6} & \multirow{6}{*}{ Self-Efficacy } & \multirow{3}{*}{ Have strong beliefs } & $\begin{array}{l}\text { 1. Confident in being able to solve } \\
\text { problems }\end{array}$ & 921 & \multirow{2}{*}{959} & \multirow{2}{*}{ B } & \multirow{3}{*}{989} & \multirow{3}{*}{ B } \\
\hline & & & $\begin{array}{l}\text { 2. Confidence in being able to change for } \\
\text { the better }\end{array}$ & 997 & & & & \\
\hline & & & $\begin{array}{l}\text { 3. Having a good attitude in dealing with } \\
\text { problems }\end{array}$ & 992 & 992 & $\mathrm{~B}$ & & \\
\hline & & \multirow{3}{*}{$\begin{array}{l}\text { Bearing everything } \\
\text { about oneself }\end{array}$} & $\begin{array}{l}\text { 1. Having ani admits not correct } \\
\text { information }\end{array}$ & 076 & \multirow{3}{*}{990} & \multirow{3}{*}{ B } & \multirow{3}{*}{974} & \\
\hline & & & 2. Complete the task completely & 940 & & & & B \\
\hline & & & 3. Ready to bear the consequences & 953 & & & & \\
\hline & & & 1. Believing there will be wisdom & 1005 & & & & \\
\hline & & Re-spirit possessed & 2 Easy to forgive others & 802 & 05 & & & \\
\hline 7 & $\begin{array}{l}\text { Achievement } \\
\text { (Reaching Out) }\end{array}$ & from adversity & 3. Trying to get up from sadness & 1058 & & & 972.5 & B \\
\hline & & & 1. Accept the reality of life & 1076 & & & & \\
\hline & & $\begin{array}{l}\text { Able to be free from } \\
\text { trauma in life }\end{array}$ & 2. Do not get carried away in the past & 940 & 990 & B & & \\
\hline & & & 3. Focus on designing the future & 953 & & & & \\
\hline
\end{tabular}

The table above shows that almost all sub-indicators have value in the scale range categorized B (Good). It appears that only one sub-indicator is in the $\mathrm{CB}$ category (good enough), namely believing in one's own ability in the aspect of optimism. It shows that the student group already had good resilience in the early pandemic, although they felt vulnerable with the optimism aspect. In addition, several other subindicators are also of particular note in this research. This particular note will later correlate with the implications that decision-making groups must make. The identification of these sub-indicators is presented in the following table:

Table 5. Identification of Sub-Indicators With Special Notes

\begin{tabular}{|c|l|c|l|}
\hline No & \multicolumn{1}{|c|}{ Sub-Indicators } & Score & \multicolumn{1}{c|}{ Aspect } \\
\hline 1 & Trying to be happy even if they get a problem & 805 & Optimism \\
\hline 2 & Understanding the causes of problems & 805 & Ability to analyze problems \\
\hline 3 & Able to find solutions to problems & 800 & Ability to analyze problems \\
\hline 4 & Easily forgive others & 802 & Achievements The \\
\hline
\end{tabular}

The table above shows several aspects and subindicators that can be a gap for student resilience vulnerabilities in the face of the Covid-19 pandemic. The sub-indicator of the ability to entertain themselves in the aspect of optimism shows a condition where students feel they have lost the opportunity to socialize and entertain each other with their friends [9]. The sub-indicator of understanding the causes of problems and the ability to find solutions to problems in the aspect of problem analysis skills shows that they experience conditions that are vulnerable to exposure to misinformation, mainly when it refers to the freedom to use social media, which is very commonly accessed by them 
[3]. Furthermore, the sub-indicator of forgiving others in the achievement aspect shows that students harbour emotions towards those who cause socioeconomic problems during this pandemic [10]. Some sub-indicators indicate that students' vulnerability still covers aspects of their internal capacity, not aggressive towards other parties. However, this condition has several implications that stakeholders must follow up. The identification can be observed from the following table:

Table 6. Identification of Issues and Implications in Student Group Resilience

\begin{tabular}{|c|c|c|}
\hline No & $\begin{array}{c}\text { Identification of } \\
\text { Issues }\end{array}$ & Implications \\
\hline 1 & $\begin{array}{l}\text { Vulnerability of } \\
\text { optimism in student } \\
\text { groups, especially in } \\
\text { terms of the ability to } \\
\text { entertain themselves }\end{array}$ & $\begin{array}{l}\text { The need for } \\
\text { educational therapy } \\
\text { interventions and } \\
\text { management of } \\
\text { public information } \\
\text { that is entertaining } \\
\text { and self-motivated }\end{array}$ \\
\hline 2 & $\begin{array}{l}\text { Vulnerability of } \\
\text { student groups to } \\
\text { experience } \\
\text { information bias, } \\
\text { especially in receiving } \\
\text { information related to } \\
\text { the causes of socio- } \\
\text { economic problems } \\
\text { caused by the } \\
\text { pandemic. }\end{array}$ & $\begin{array}{l}\text { The need for } \\
\text { intervention in the } \\
\text { management of } \\
\text { public information, } \\
\text { specifically related to } \\
\text { Hoax and } \\
\text { Disinformation. }\end{array}$ \\
\hline 3 & $\begin{array}{l}\text { vulnerability of } \\
\text { student groups to } \\
\text { disinformation, } \\
\text { especially regarding } \\
\text { solutions to problems } \\
\text { generated during the } \\
\text { pandemic. }\end{array}$ & $\begin{array}{l}\text { The need for } \\
\text { campaigns and } \\
\text { dissemination of } \\
\text { correct and valid } \\
\text { information on public } \\
\text { information channels. }\end{array}$ \\
\hline 4 & $\begin{array}{l}\text { Vulnerability of } \\
\text { student groups to } \\
\text { experience emotional } \\
\text { conditions, especially } \\
\text { those considered to } \\
\text { have caused various } \\
\text { problems during the } \\
\text { pandemic. }\end{array}$ & $\begin{array}{l}\text { The need for mutual } \\
\text { support and trauma } \\
\text { healing movements } \\
\text { through public } \\
\text { information channels } \\
\text { or social media. }\end{array}$ \\
\hline
\end{tabular}

Some of the implications in the table above indicate the need for several interventions or movements to overcome various issues around the resilience of student groups during the pandemic. Some interventions are educative, structured, neutralizing and trauma healing through various information channels, both formal and non-formal [11]. The resilience of a community group requires support from many parties or other groups that become the environment of the student group [12]. The capacity building is parallel with all parties and requires policy and institutional initiatives to maintain coordination.

\section{CONCLUSION}

The resilience capacity of student groups in Lampung Province in dealing with the Covid-19 pandemic is in a Good category, where almost all indicators and subindicators are in the Good scale range. However, there are several sub-indicators of particular note. The category of the scale range on the sub-indicator is below the average value of the other subindicators. The sub-indicators that become special notes become the background for several implications that need to be followed up or intervened by stakeholders or policymakers. In the future, it is necessary to conduct a more detailed study of the factors that can maintain optimal resilience capacity.

\section{REFERENCES}

[1] F. Firman and S. Rahayu, 'Pembelajaran Online di Tengah Pandemi Covid-19', Indonesian Journal of Educational Science (IJES), vol. 2, no. 2, Art. no. 2, Apr. 2020, doi: 10.31605/ijes.v2i2.659.

[2] C. L. Pandey, 'Making communities disasterresilient: Challenges and prospects for community engagement in Nepal', Disaster Prevention and Management: An International Journal, vol. 28, no. 1, pp. 106-118, Jan. 2019, doi: 10.1108/DPM-05-2018-0156.

[3] D. Blackman, H. Nakanishi, and A. M. Benson, 'Disaster resilience as a complex problem: Why linearity is not applicable for long-term recovery', Technological

Forecasting and Social Change, vol. 121, pp. 89-98, Aug. 2017, doi:

10.1016/j.techfore.2016.09.018.

[4] S. Espiner, C. Orchiston, and J. Higham, Resilience and sustainability: a complementary relationship? Towards a practical conceptual model for the sustainability-resilience nexus in tourism', Journal of Sustainable Tourism, vol. 25, no. 10, pp. 1385-1400, Oct. 2017, doi: 10.1080/09669582.2017.1281929.

[5] K. Reivich and A. Shatté, The resilience factor: 7 essential skills for overcoming life's 
inevitable obstacles. New York, NY, US: Broadway Books, 2002, p. 342.

[6] Disdukcapil Lampung, 'Jumlah Penduduk Provinsi Lampung Semester II Tahun 2019 Dinas Kependudkan Dan Pencatatan Sipil Provinsi Lampung', 2020.

https://disdukcapil.lampungprov.go.id/detailpost/jumlah-penduduk-provinsi-lampungsemester-ii-tahun-2019 (accessed Dec. 21, 2020).

[7] Sugiyono, Metode Penelitian Kualitatif, Kuantitatif dan RD. Bandung: Alfabeta, 2007.

[8] I. Etikan, 'Sampling and Sampling Methods', $B B I J$, vol. 5, no. 6, May 2017, doi: 10.15406/bbij.2017.05.00149.

[9] D. Paton and D. Johnston, Disaster Resilience: An Integrated Approach (2nd Ed.). Charles C Thomas Publisher, 2017.
[10] N. Etinay, C. Egbu, and V. Murray, 'Building Urban Resilience for Disaster Risk Management and Disaster Risk Reduction', Procedia Engineering, vol. 212, pp. 575-582, Jan. 2018, doi: 10.1016/j.proeng.2018.01.074.

[11] R. Jain and S. Jain, The Science and Practice of Wellness: Interventions for Happiness, Enthusiasm, Resilience, and Optimism (HERO). W. W. Norton \& Company, 2020.

[12] T. L. O'Sullivan, C. E. Kuziemsky, D. ToalSullivan, and W. Corneil, 'Unraveling the complexities of disaster management: A framework for critical social infrastructure to promote population health and resilience', Social Science \& Medicine, vol. 93, pp. 238246, Sep. 2013, doi:

10.1016/j.socscimed.2012.07.040. 